\title{
Organic Quality of Groundwaters
}

\author{
D C Gooddy, K Hinsby
}

\begin{abstract}
Organic carbon is present in all natural waters and plays an important role in many geochemical processes. Total organic carbon (TOC), measured on unfiltered samples, has been analysed on more than 400 groundwater samples from 8 European Union countries, and the operationally defined dissolved organic carbon (DOC), measured on filtered samples, was analysed on approximately 250 groundwater samples from 4 of these countries. TOC was found at a median concentration of $2.7 \mathrm{mg} \mathrm{C} / \mathrm{L}$ with a range from $0.1-59.4 \mathrm{mg} \mathrm{C} / \mathrm{L}$ and DOC had a median concentration of $2.2 \mathrm{mg} \mathrm{C} / \mathrm{L}$ with a range from $0.2-58.9 \mathrm{mg} \mathrm{C} / \mathrm{L}$, demonstrating that very high natural organic carbon values can occasionally be found locally in some pristine aquifers. A relationship between the assimilable organic carbon (AOC) utilised by bacteria and TOC is observed although the correlation is not clear. Generally, there is a linear correlation between the TOC, DOC and the chemical oxygen demand (COD) values. Organic contaminants derived from anthropogenic activities are generally not identified in the TOC/DOC analysis as these contaminant concentrations are typically several orders of magnitude lower than the bulk aqueous carbon measurement. TOC/DOC analysis can, however be an important indicator of pollution at landfills, effluent ponds and similar pollution settings with high loads of organic carbon, but in many other situations the total or dissolved organic carbon concentration is not a good tracer or indicator of contamination. However, the total or dissolved organic carbon is a very important component in the biogeochemical cycling of elements and consequently it is recommended as a component to be measured on all groundwater samples. The measurement of a filtered organic carbon fraction is recommended where groundwaters contain significant amounts of particulate material. Measurements of TOC and DOC on the same samples in this study show comparable concentrations, however, the TOC/DOC ratio varied and TOC was not always found to be significantly greater than DOC, as may have been expected. Further investigations are needed to find the reasons for this. Further research is also needed to evaluate what part of the TOC is readily available for biogeochemical processes. Increased knowledge on this issue would help to understand better the development of the different redox environments and associated bacterial regrowth which occurs in water supply systems.
\end{abstract}

\section{Introduction}

All natural waters contain dissolved organic compounds. Geochemists have tended to ignore them in the past because they are complex and difficult to analyse, but it is now recognised that they play a significant role in weathering processes (Heyes and Moore, 1992; Shand et al., 2005), in diagenesis (Bottrell, 1996) and in the transport of trace metals (Benedetti et al., 1996). Organic carbon concentrations can vary considerably, both spatially and temporally, so a large number of analyses are frequently required to produce a representative estimate of concentrations.

Natural organic carbon is mainly derived from decomposing vegetation and other organic matter in the soil zone. In solution it has a characteristic yellow/brown straw colour (Gooddy et al., 1995) and is found in surface waters, and to a lesser extent, in shallow groundwaters. Seminal work from the United States indicated that DOC concentrations in shallow groundwaters range between 0.1-4 mg C/l which is higher than organic carbon concentrations in deep seated aquifers (Leenheer et al., 1974; Junk et al., 1980). The generic term 'humic 
substance' is commonly applied to the dissolved organic matter in all natural waters. It has been shown that humic substances constitute up to $90 \%$ of the organic carbon in Canadian groundwater systems (Thurman, 1985). Humic substances encompass a wide range of organic macro-molecules, both hydrophobic and hydrophilic, and mainly consisting of fulvic and humic acids. Fulvic acids predominate in most waters because they are smaller, lighter (both in terms if colour and molecular weight) and contain more solubilising functional groups, whilst humic acids are darker, heavier and generally insoluble in acid waters. The remaining humic substances are a complex mixture of lower molecular weight compounds. Some of the more hydrophobic organic compounds present in surface and recharge waters will be sorbed onto the aquifer solids. Deeper and older waters may contain organic material which has been mobilised from the aquifer matrix (Grøn et al., 1996, Orem et al. 1999) such as lower molecular weight compounds resulting from kerogen degradation or bitumen dissolution.

The natural organic carbon content of groundwater is generally not a health concern in itself, but exceptions have been reported (e.g. Orem et al., 1999). There is however no general standard or guideline value for the total contents of organic carbon in groundwater. Organic carbon in groundwater can also be derived from anthropogenic sources. Anthropogenically derived carbon typically occurs at much lower concentrations (generally 2-4 orders of magnitude), but the organic pollutants, such as chlorinated solvents and pesticides, are both more toxic and a health concern at these lower concentrations. Additionally, chlorination may create carcinogenic by-products like trihalomethanes (THMs) in groundwater (Stuart et al., 2001).

Increased understanding regarding the evolution and variation of natural organic and inorganic groundwater quality is much needed as a basis for the recognition of human impacts on aquifers and for aquifer management. We present baseline values for the non volatile organic carbon (NVOC) fraction expressed as total dissolved organic carbon (TOC) and dissolved (passed through a $0.45 \mu \mathrm{m}$ filter) organic carbon (DOC) in groundwaters, which are comparable to earlier North American studies (Leenheer et al., 1974; Malcolm, 1993; Thurman, 1985). These were selected from 20 European reference aquifers. TOC and DOC were analysed in groundwaters from more than 300 wells. The number of bacteria, the concentration of readily assimilable organic carbon (AOC) and the chemical oxygen demand (COD) were also determined in selected samples from Denmark.

\section{Measured Organic Fractions}

TOC (total organic carbon) and DOC (dissolved organic carbon) measurements are standard methods globally used for measuring the amount of organic carbon in water samples (ASTM, 1988; Barcelona, 1984). TOC measurements include all organic compounds in the analysed water sample and thus include suspended particles and bacteria in addition to a large number of dissolved organic macro-molecules of different sizes (Figure 1). DOC measurements are performed on filtered samples (conventionally $0.45 \mu \mathrm{m}$ silver filters although polycarbonate filters are increasingly being used) so that most suspended/“particulate” carbon is removed, but some viruses and small bacteria may still pass through the filter. Sampling requires the use of stainless steel filter systems and silver or polycarbonate membranes into glass bottles. The usual groundwater sampling for inorganic constituents requires plastic filter systems and bottles, the use of which can cause erroneously high results for DOC measurements, a problem which may be especially prevalent in older data-sets.

Isolation and characterisation of DOC from groundwater presents a particular challenge because of the low concentrations and potential interference from inorganic ions. In earlier 
studies, DOC was chemically fractionated using XAD-8 and XAD-4 resin into acids (humic and fulvic), bases, and neutrals (Leenheer, 1981). This approach was largely replaced with an isolation procedure utilising DEAE-cellulose, a weak anion exchange resin which can adsorb humics without any $\mathrm{pH}$ adjustment of the sampled water (Pettersson et al., 1994). More recent studies have relied on ultrafiltration to concentrate DOC fractions providing high recovery, and requiring no need for $\mathrm{pH}$ adjustment or other chemical reagents (Crum et al., 1996). DOC fractions separated and concentrated in this way are operationally defined on the molecular weight cut-off of the ultrafiltration membrane. A comparatively new technique in groundwater studies exploits the fluorescent nature that is possessed by dissolved organic matter (Baker and Lamont-Black, 2001). Fluorescence excitation-emission spectra exhibit discrete intensity peaks at known wavelengths which can be ascribed to different organic functional groups. This method requires no prior sample processing and is both rapid and requires only a very small sample volume especially when compared with other characterisation techniques. The possibility of combining ultrafiltration techniques with fluorescence excitation-emission spectra for better characterisation of dissolved organic matter is currently an area of on-going research.

Organic carbon is generally very important for the evolution of different redox regimes in aqueous environments, and the amount and reactivity of the organic carbon in the aquifers is therefore an important parameter when evaluating the state and trends of groundwater quality. However, the amount of TOC/DOC itself does not provide information on how reactive or reducing the environment is. Generally, the biologically viable TOC/DOC in European groundwaters is likely to originate from the soil, as any organic matter present in the rock matrix is mostly unavailable to microorganisms. Exceptions do exist though in shallow aquifers which may contain young reactive organic matter (Jakobsen and Postma, 1999; Hansen et al., 2001). The majority of DOC that travels from the soil zone to deep within the aquifer will be old and highly recalcitrant, and therefore not prone to further microbial breakdown over the timescales of more active groundwater circulation (Darling and Gooddy, 2006). Groundwater with a small but very reactive amount of "young” organic carbon may be much more reactive than groundwater with a much larger but "old" non-degradable amount of organic carbon. It is important to note that the typical phenoxy, hydroxy and carboxylic multifunctionality of the dissolved organic matter has an important role to play in ion-exchange, metal chelation and transport processes in groundwaters (Koopal et al., 2001)

The degradability of organic carbon is not only important for the "health" of the aquifers (Grøn et al. 1992), but also for the water supply systems (DEPA 2002). The amount of highly "reactive" organic carbon, may be estimated by the method proposed by Van der Kooij et al. (1982). This method estimates the readily assimilable organic carbon (AOC) i.e. the part of the total organic carbon in the water which is easily available to aerobic bacteria. High AOC contents may cause bacterial growths in the aquifers or a problem with bacterial regrowth in water pipelines if the water is not adequately disinfected/chlorinated (Van der Kooij, 1992, DEPA 2002). In general, groundwater has lower AOC values than surface waters (Jørgensen 2000). Water chlorination, on the other hand, is known to cause carcinogenic disinfection byproducts when chlorine reacts with the dissolved organic carbon (Stuart et al., 2001), and it is therefore often avoided if possible (DEPA 2002). AOC concentrations are often much lower than TOC/DOC concentrations typically 2-3 orders of magnitude in Danish groundwater (DEPA 2002) although in some cases they may be close to the TOC/DOC values. Large AOC values indicate young, potentially contaminated groundwater or relatively young and highly reactive organic carbon in the aquifer sediments. Large AOC values also show that the groundwater has a significant potential for reducing oxygen and nitrate concentrations and hence that reduced geochemical environments in the aquifers should develop relatively fast. 


\section{Description of Investigated Aquifers}

Fourteen different aquifers were selected for TOC analysis in groundwater in 8 EU countries (Figure 2, Table 1 and 2). The sampled aquifers can be grouped into 3 major aquifer types: i. sand (including gravel) ii. carbonates (chalk/limestone) and iii. sandstone. The aquifer sediments were deposited in different geological periods from the Devonian sandstone in Estonia, which is more than 350 million years old, to the relatively recent unconsolidated Quaternary sand aquifers in Portugal and Spain, less than 2 million years old. Hence the dataset contains analyses from aquifers representing deposits from the last three geological eras: the Palaeozoic, Mesozoic and Cenozoic. The aquifer sediments represent several transitional, terrestrial and marine depositional environments which, at the time of deposition, have contained varying amounts of organic matter.

Most of the investigated aquifers are unconsolidated sands or sandstones, illustrating that these are the most common and important aquifer types in Europe. The sands and sandstones range from unconsolidated, mature, very pure quartz sands to arkosic immature sandstones. Four of the investigated aquifers or aquifer systems are composed of various kinds of carbonates or include a carbonate, which is also among the most common and important aquifer types in Europe. The carbonates range from fine grained Chalk to Bryozoan limestone with large fragments of Bryozoa and other marine animals. The distribution of TOC concentrations in the selected aquifer waters is believed to illustrate the most common distribution of TOC values in European aquifers. The investigated aquifers are generally semi-confined and recharged either directly, or through Quaternary deposits of varying thickness. Table 1 lists the name and some basic geological information about the investigated aquifers.

\section{Results}

\section{TOC Concentrations}

Results from the 8 EU study countries for TOC are statistically summarised in Table 2 and shown graphically in Figure 2. For most of the countries there is a fairly large discrepancy between the Mean and Median values which reflects the extreme concentration of the outliers (see black circles on Figure 2) especially for Denmark. For the two countries with the lowest TOC concentration in groundwater, Poland and Estonia, the mean and median concentrations are very similar. The sample set for France is too small to be statistically significant and is included only for comparison.

\section{DOC Concentrations}

A limited number of samples from Denmark, England, France and Poland were also analysed for the DOC fraction. Table 3 shows the range of values obtained for these four countries. The high overall mean concentration is probably a reflection of a few very high organic carbon concentration waters from Denmark. These samples bias the statistical evaluation since they were specifically collected from wells known to have high TOC values in order to demonstrate the possible large range of natural organic carbon in groundwater. 


\section{Comparing TOC and DOC data}

A cummulative frequency plot for the TOC (based on 439 analyses) and for the DOC (based on 246 analyses) is shown in Figure 3. The curve shape is typical of a lognormal distribution and indicates that both populations resemble this form of statistical function. The very high concentration outliers from Denmark which exceed $50 \mathrm{mg} \mathrm{C/l}$ occur in the top 99.5 percentile and so are not shown on the plot.

A direct comparison made between DOC and TOC samples collected in the UK is shown in Figure 4a. A fairly weak positive correlation is observed between the two parameters $\left(\mathrm{R}^{2}=0.32\right)$ with TOC generally lower in concentration than DOC, suggesting perhaps some degradation of the organic carbon in the unfiltered samples between sampling and analysis which may be due to microbial action.

In comparison, Figure 4b shows a cross plot for DOC and TOC samples collected in Poland. The range of values is much smaller but also the two parameters are much more closely correlated $\left(\mathrm{R}^{2}=0.81\right)$ with TOC values being roughly $8 \%$ higher than the DOC values, more likely reflecting a degree of particulate matter in the unfiltered fraction.

\section{Comparing TOC between Aquifers}

Figure 5a shows an example of TOC data for two Permo-Triassic sandstone aquifers and two Chalk aquifers both from the UK. The data suggest a much broader range of concentrations for the Permo-Triassic sandstones with generally higher TOCs.

In contrast, Figure 5b shows the same data but with the data split based on aquifer type and region. Permo-Triassic sandstones from Cheshire and the Vale of York show quite different properties, with the Vale of York encompassing a greater range of values. Similarly there are considerable differences between Chalk from the Dorset region and Chalk from the Thames region of the UK. This highlights the difficulties encountered when only considering aquifer types.

This is also illustrated by a recent study performed on data from the National Danish groundwater monitoring database. This study demonstrates TOC values comparable to the British values illustrated in Figure 5. However, here the different types of silicious rocks (unconsolidated Tertiary and Quaternary sands) show slightly lower average TOC concentrations than most Danish carbonate rock types e.g. the Bryozoan limestones (Ernstsen et al. 2005).

\section{Comparing TOC With Other Parameters}

Measurement of TOC can be problematic and in itself not necessarily a meaningful parameter. Accordingly, TOC values measured as part of the Danish National Monitoring programme (Czako 1994, Henriksen and Stockmarr 2000) have been compared with the chemical oxygen demand (COD) in Figure 6a. A good positive correlation can be seen between the two parameters $\left(\mathrm{R}^{2}=0.86\right)$ with $\mathrm{COD}$ values approximately 2.7 times greater than TOC values. The value of 2.7 corresponds to the ratio of the atomic mass between oxygen $\left(\mathrm{O}_{2}\right.$ $=32$ ) and Carbon (12). As the reduced carbon compounds are oxidised to $\mathrm{CO}_{2}$ this indicate that organic carbon is quantitatively the only important element, which has been oxidised in the investigated groundwaters. This will probably be the case for many natural groundwaters globally, although other reducing elements like ferrous iron, will be quantitatively important in some natural groundwater types. COD often requires a considerably larger volume of water for determination than a TOC measurement so a simple factor difference makes for an easy conversion between the two parameters. 
TOC has also been compared with the amount of assimilable organic carbon (AOC) in Figure $6 \mathrm{~b}$ (note scale difference). The data are from this study and from a study performed by the Water Resources Division of Copenhagen Energy. No strong correlation is observed although generally, higher concentrations of TOC are concomitant with higher AOC. This is likely to relate to the structure of the TOC in the groundwater and would take considerably more time to characterise, although this is a relationship that should be investigated further in the future.

\section{Discussion}

By understanding the range of baseline organic carbon concentrations in groundwater it is possible to use this parameter as an indicator of groundwater contamination at sites with high loads of organic carbon (e.g. Christensen et al. 2001; Gooddy et al., 2002) simply by comparing concentrations of dissolved organic carbon. In a review of landfill studies Christensen et al. (2001) have shown that there is a decline in both the volatile and nonvolatile fraction of the organic carbon concentration with increasing distance from mixed landfill sites. The concentrations found in a specific study conducted by Baun et al. (2000), which are fairly typical at mixed landfills, are considerably above any of the maximum detected natural background concentrations found in our study for at least the first $50 \mathrm{~m}$ downgradient of the landfill, and they remain above the overall median groundwater TOC concentration for more than $150 \mathrm{~m}$. This would also indicate a considerable increase in the load of microbiologically available carbon originating in the landfill, which can lead to the formation of distinct redox zones and subsequent mobilisation of natural or leachate derived heavy metals from the landfill.

A number of studies in the UK carried out by Gooddy et al. (2002) measured the dissolved organic carbon concentrations beneath unlined waste lagoons used for storing cattle manure. Concentrations up to $200 \mathrm{mg} \mathrm{C} / \mathrm{l}$ can be observed, nearly 100 times greater than a typical groundwater value observed in the reference aquifers. These lagoons also form distinct redox zones beneath them in a similar manner to the landfill example cited above.

Not all detections of a high concentration of dissolved organic carbon are, however, indicative of contamination. Some of the unusual samples found in the reference aquifer from Denmark have organic carbon concentrations up to more than $100 \mathrm{mg} \mathrm{C} / \mathrm{L}$. The high carbon concentration manifests itself in the form of a dark brown coloured liquid rich in naturally derived fulvic and humic acids, which occur in these particular aquifer sediments (Hinsby et al. 2001). Such occurrences are however extremely rare, the 95 percentile is below $10 \mathrm{mg} \mathrm{C} / \mathrm{L}$ TOC for all Danish aquifer types. Organic carbon rich waters may be found both in deep aquifer systems (> $100 \mathrm{~m}$ below surface) like in the Danish cases (Grøn et al. 1996, Jørgensen et al., 1999, Hinsby et al. 2001) and in shallow soil, bog and aquifer sediments (e.g. Weis et al., 1989, Ernstsen et al. 2005). In case of doubts on the origin of the organic carbon further characterisation of the composition is needed (Weiss et al. 1989, Grøn et al. 1996).

Where groundwaters contain dissolved organic carbon they are also susceptible to forming trihalomethanes (THMs), which are known carcinogens, during the chlorination processes at the water treatment works. Stuart et al. (2001) demonstrated a relationship between the potential to form THMs following chlorination and the amount of dissolved organic carbon present in the water. The relationship was well correlated $\left(\mathrm{R}^{2}>0.9\right)$ and showed increasing formation of THMs with increasing concentrations of DOC. This is a concern for water managers and water authorities from both uncontaminated and contaminated groundwater with relatively high concentrations of organic carbon. 
The use of TOC and DOC as indicators of groundwater contamination also has its limitations. Johnson et al. (2001) examined the changes in concentration of two pesticides that occurred over a year in groundwater following their application to the overlying soil. Peaks in pesticide concentration were found to vary by nearly an order of magnitude. However, it is not possible to obtain a low enough limit of detection and this level of sensitivity (roughly 3 orders of magnitude lower) with organic carbon analysis. Consequently these concentrations, which exceeded the EC MAC values, would go undetected if trying to observe such contamination by dissolved organic carbon analysis alone. Similarly, other micropollutants such as chlorinated solvents will generally not be identified as groundwater contaminants by organic carbon analysis.

\section{Conclusions and Recommendations}

The results of the groundwater sampling show that the baseline values for TOC and DOC are comparable. The mean and median concentrations were around $2 \mathrm{mg} \mathrm{C} / \mathrm{L}$, while minimum and maximum values ranged from $<0.5 \mathrm{mg} \mathrm{C} / \mathrm{L}$ to $>50 \mathrm{mg} \mathrm{C} / \mathrm{L}$. The AOC seems to correlate with TOC although the correlation is not clear and needs to be investigated further. Generally, there is a linear correlation between the TOC, DOC and the COD values. Very high dissolved natural organic carbon values were found locally in some pristine aquifer waters. Higher concentrations of DOC can lead to greater formation of trihalomethanes following chlorination. Organic contaminants derived from anthropogenic activities (e.g. pesticides and chlorinated solvents) are generally not identified in the TOC/DOC analysis as the contaminant concentrations are typically 3-4 orders of magnitude lower than the natural dissolved carbon concentrations. In many situations organic carbon concentration is not a good tracer or indicator of contamination; however, it is an important component in the biogeochemical cycling of elements and consequently it is recommended as a component to be measured on all groundwater samples. The measurement of a correctly filtered organic carbon fraction (DOC) is to be recommended where groundwaters contain significant amounts of particulate material, otherwise, the more operationally simple and cheaper TOC measurement can be made. Measurements of the reactive part of the organic carbon readily available for microbiological processes provide valuable additional information and should be developed further as should techniques to better characterise dissolved organic carbon.

\section{References}

ASTM (1988). Standard D-4129-88: Test method for total organic carbon in water, pp85-90.

Baker, A. and Lamont-Black, J. (2001) Fluorescence of dissolved organic matter as a natural tracer of groundwater. Ground Water 39, 745-750.

Barcelona, M.J. (1984) TOC determinations in groundwater. Ground Water 22, 18-24.

Baun, A., Jensen, S.D., Berg, P.L. et al. (2000) Toxicity of organic chemical pollution in groundwater downgradient of a landfill (Grindsted, Denmark). Environmental Science and Technology 34, 1647-1652.

Benedetti, M.F, Van Riemsdijk, W.H., Koopal, L.K., Kinniburgh, D.G., Gooddy, D.C. \& Milne, C.J. (1996) Metal ion binding of natural organic matter; from the laboratory to the field. Geochimica et Cosmochimica Acta 60, 2503-2513.

Bottrell, S.H. (1996) Organic carbon concentration profiles in recent cave sediments: Records of agricultural pollution or diagenesis? Environmental Pollution 91, 325-332. 
Christensen, T.H., Kjeldsen, P., Bjerg, P.L., et al. (2001) Biogeochemistry of landfill leachate plumes. Applied Geochemistry 16, 659-718.

Crum, R.H., Murphy, E.M. \& Keller, C.K. (1996) A non-adsorptive method for the isolation and fractionation of natural dissolved organic carbon. Water Research 30, 1304-1311.

Czakó, T. (1994) Groundwater monitoring network in Denmark: example of results in the Nyborg Area. Hydrological Sciences Journal 39, 1-17.

Darling, W.G. and Gooddy, D.C. (2006) The hydrogeochemistry of methane: evidence from English groundwaters. Chemical Geology 229, 293-312.

Ernstsen, V., Larsen, C.L. and Tougaard, L. (2005) NVOC krav til drikkevand. Arbejdsrappport fra Miljøstyrelsen Nr. 18 2005, Report for the Danish EPA, Geological Survey of Denmark and Greenland (In Danish).

DEPA. (2002) Investigation of number of bacterial cells and regrowth potential in drinking water. Danish Environmental Protection Agency, Miljøstyrelsen, Report: Miljøprojekt 719, In Danish (English summary), on-line report at: http://www.mst.dk/udgiv/publikationer/2002/87-7972-246-6/html/indhold.htm.

Gooddy, D.C., Clay, J.W. and Bottrell, S.H. (2002) Redox-driven changes in pore-water chemistry of the Chalk unsaturated zone beneath unlined cattle slurry lagoons. Applied Geochemistry 17, 903-921.

Gooddy, D.C., Shand, P., Kinniburgh, D.G. et al. (1995) Field-based partition coefficients for trace elements in soil solutions. European Journal of Soil Science 46, 265-285.

Grøn, C., Tørslev, J., Albrechtsen, H.-J. et al. (1992) Biodegradability of dissolved organic carbon from an unconfined aquifer. Science of the Total Environment 117/118, 241-251.

Grøn, C., Wassenaar, L. andKrog, M. (1996) Origin and structures of groundwater humic substances from three Danish aquifers. Environment International 22, 519-534.

Hansen, L.K., Jakobsen, R. and Postma, D. (2001) Methanogenesis in a shallow sandy aquifer, Romo, Denmark. Geochimica et Cosmochimica Acta 65, 2925-2935.

Henriksen, H.J. and Stockmarr J. (2000) Ground water resources in Denmark, modelling and monitoring. Water Supply 18, 550-557.

Heyes, A. and Moore, T.R. (1992) The influence of dissolved organic-carbon and anaerobic conditions of mineral weathering. Soil Science 154 , 226-236.

Hinsby, K., Harrrar, W.G., Nyegaard, P., et al. (2001) The Ribe Formation in western Denmark - Holocene and Pleistocene groundwaters in a coastal Miocene sand aquifer. In: Edmunds, W.M. \& Milne, C.J. (eds.) Palaeowaters in Coastal Europe: evolution of groundwater since the late Pleistocene. Special Publication 189. The Geological Society, London, 29-48.

Jakobsen, R. and Postma, D. (1999) Redox zoning, rates of sulfate reduction and interactions with Fe-reduction and methanogenesis in a shallow sandy aquifer, Romo, Denmark. Geochimica et Cosmochimica Acta. 63, 137-151.

Johnson, A.C., Besien, T,J., Bhardwaj, C.L., et al. (2001) Penetration of herbicides to groundwater in an unconfined chalk aquifer following normal soil applications. Journal of Contaminant Hydrology 53, 101-117.

Jørgensen, C. (2000) Removal of AOC and NVOC during artificial recharge - Investigation at the Arrenæs site. Final report of EU project ENV4-CT95-0071. 
Jørgensen, N.O., Morthorst, J. and Holm, P.M. (1999) Strontium-isotope studies of "brown water” (organic-rich groundwater) from Denmark. Hydrogeology Journal 7, 533-539.

Junk, G.A., Spalding, R.F. and Richard, J.J. (1980) Areal, vertical and temporal differences in ground water chemistry, II. Organic constituents. Journal of Environmental Quality 9, 479483.

Koopal, L.K., van Riemsdijk, W.H. and Kinniburgh, D.G. (2001) Humic matter and contaminants. General aspects and modelling metal ion binding. Pure and Applied Chemistry 73, 2005-2016.

Leenheer, J.A., Malcolm, R.L., McKinley, P.W. et al. (1974) Occurrence of dissolved organic carbon in selected groundwater samples in the United States. Journal of Research of the US Geological Survey 2, 361-369.

Leenheer, J.A. (1981) Comprehensive approach to preparative isolation and fractionation of dissolved organic carbon from natural waters and wastewaters. Environmental Science and Technology 15, 578-587.

Malcolm, R.L. (1993) Concentration and composition of dissolved organic carbon in soils, streams, and groundwaters. In: Beck, A.J., Jones, K.C., Hayes, M.H.B. \& Mingelgrin, U (eds) Organic substances in soil and water: natural constituents and their influences on contaminant behaviour. Special Publication 193. The Royal Society of Chemistry, Cambridge, 19-29.

Orem, W.H., Feder, G.L. and Finkelman, R.B. (1999) A possible link between Balkan endemic nephropathy and the leaching of toxic organic compounds from Pliocene lignite by groundwater; preliminary investigation. International Journal of Coal Geology 40, 237-252.

Pettersson, C., Ephraim, J. and Allard, B. (1994) On the composition and properties of humic substances isolated from deep groundwater and surface waters. Organic Geochemistry 21, 443-451.

Shand, P., Haria, A.H., Neal, C., et al.. (2005) Hydrochemical heterogeneity in an upland catchment: further characterisation of the spatial, temporal and depth variations in soils, streams and groundwaters of the Plynlimon forested catchment, Wales. Hydrology and Earth System Sciences 9, 611-634.

Stuart, M.E., Gooddy, D.C., Kinniburgh, D.G. et al. (2001) Trihalomethane Formation Potential: A Tool For Detecting Non-Specific Organic Groundwater Contamination. Urban Water 3, 197-208.

Thurman, E.M. (1985) Organic geochemistry of natural waters. Martinus Nijhoff/Dr W. Junk Publishers, Dordrecht. 497pp.

Van der Kooij, D. (1992). Assimilable organic carbon as an indicator of bacterial regrowth. Journal of the American Water Works Association 84, 57-65

Van der Kooij, D., Visser, K.A. and Hijnen, W.A.M. (1982) Determining the concentration of easily assimilable organic carbon in drinking water. Journal American Water Works Association 74, 540-545.

Weiss, M., Abbt-Braun, G. and Frimmel, F.H. (1989) Humic-like substances from landfill leachates-characterization and comparison with terrestrial and aquatic humic substances. Science of the Total Environment, 82/83, 343-352. 
Table 1. Summary of aquifer types used in this Baseline study.

\begin{tabular}{|c|c|c|c|c|c|}
\hline Country & Aquifer name & Type & Geol. Period & $\begin{array}{l}\text { Age } \\
(\mathrm{myr})^{*}\end{array}$ & $\begin{array}{c}\text { Depos. } \\
\text { onment }\end{array}$ \\
\hline Belgium & Ledo-Paniselian & Sand & $\begin{array}{l}\text { Neogene } \\
\text { (Miocene) }\end{array}$ & $>5$ & Marine \\
\hline Denmark & $\begin{array}{l}\text { Ribe Formationen } \\
\text { Bryozokalk }\end{array}$ & $\begin{array}{l}\text { Sand } \\
\text { Bryozoan } \\
\text { limestone }\end{array}$ & $\begin{array}{l}\text { Neogene } \\
\text { (Miocene) } \\
\text { Paleogene }\end{array}$ & $\begin{array}{l}>5 \\
>55\end{array}$ & $\begin{array}{l}\text { (Fluvio)-deltaic } \\
\text { Marine }\end{array}$ \\
\hline England & $\begin{array}{l}\text { Cheshire } \\
\text { Dorset } \\
\text { Thames } \\
\text { Vale of York }\end{array}$ & $\begin{array}{l}\text { Sandstone } \\
\text { Chalk } \\
\text { Chalk } \\
\text { Sandstone }\end{array}$ & $\begin{array}{l}\text { Permo-Triassic } \\
\text { Cretaceous } \\
\text { Cretaceous } \\
\text { Permo-Triassic }\end{array}$ & $\begin{array}{l}>200 \\
>65 \\
>65 \\
>200\end{array}$ & $\begin{array}{l}\text { Aeolian/fluvial } \\
\text { Marine } \\
\text { Marine } \\
\text { Aeolian/fluvial }\end{array}$ \\
\hline Estonia & $\begin{array}{l}\text { Middle Devonian } \\
\text { (D2) }\end{array}$ & Sandstone & Devonian & $>350$ & Marine/Deltaic \\
\hline France & Valreas & Sandstone & $\begin{array}{l}\text { Neogene } \\
\text { (Miocene) }\end{array}$ & $>5$ & Marine \\
\hline Poland & $\begin{array}{l}\text { Bogucice } \\
\text { Kedzierzyn- } \\
\text { Glubczyce }\end{array}$ & $\begin{array}{l}\text { Sandstone } \\
\text { Sand }\end{array}$ & $\begin{array}{l}\text { Neogene } \\
\text { (Miocene) } \\
\text { Neogene } \\
\text { (Miocene) }\end{array}$ & $\begin{array}{l}>5 \\
>5\end{array}$ & $\begin{array}{l}\text { Marine } \\
\text { Barrier/shallow } \\
\text { Marine }\end{array}$ \\
\hline Portugal & $\begin{array}{l}\text { Aveiro Quaternary } \\
\text { Aveiro Cretaceous }\end{array}$ & $\begin{array}{l}\text { Sand } \\
\text { Sandstone/limest } \\
\text { one }\end{array}$ & $\begin{array}{l}\text { Neogene } \\
\text { (Pleistocene) } \\
\text { Cretaceous }\end{array}$ & $\begin{array}{l}>0.01 \\
>65\end{array}$ & $\begin{array}{l}\text { Fluvial/Aeolian } \\
\text { Transitional } \\
\text { Fluvial/Deltaic/ } \\
\text { Marine }\end{array}$ \\
\hline Spain & $\begin{array}{l}\text { Doñana aquifer } \\
\text { system }\end{array}$ & Sand & $\begin{array}{l}\text { Neogene } \\
\text { (Plio- } \\
\text { Pleistocene) }\end{array}$ & $>1$ & $\begin{array}{l}\text { Eolian, fluvial, } \\
\text { fluvio-deltaic }\end{array}$ \\
\hline
\end{tabular}

* The listed ages are not exact ages for the aquifer sediments but the minimum age of the geological period in which the aquifer sediment was deposited. 
Table 2. Statistical Summary for TOC in investigated European Groundwater. All measurements are in $\mathrm{mg} \mathrm{C/L}$. Data from the Danish national monitoring programme (Denmark NMP) is included for comparison.

\begin{tabular}{lrlllll}
\hline Country & n & Min & Max & Median & Mean & StDev \\
\hline Belgium & 18 & 1.22 & 10.5 & 2.72 & 3.26 & 2.05 \\
Denmark & 46 & 0.70 & 59.4 & 1.99 & 4.50 & 10.4 \\
England & 101 & 0.49 & 19.2 & 1.96 & 3.02 & 3.06 \\
Estonia & 19 & 0.15 & 1.90 & 0.80 & 0.83 & 0.46 \\
France & 5 & 0.60 & 3.33 & 2.03 & 1.82 & 1.08 \\
Poland & 120 & 0.31 & 5.69 & 1.31 & 1.43 & 0.85 \\
Portugal & 120 & 0.12 & 19.3 & 3.25 & 4.26 & 3.22 \\
Spain & 10 & 0.26 & 7.75 & 0.74 & 2.40 & 2.99 \\
\hline & & & & & & \\
Mean & & 0.48 & 15.9 & 1.85 & 2.69 & 3.01 \\
\hline Denmark NMP & 9883 & 0.10 & 71 & 1.4 & 2.0 & 2.5 \\
\hline
\end{tabular}


Table 3. Statistical Summary for DOC investigated European Groundwater. All measurements are in $\mathrm{mg} \mathrm{C} / \mathrm{L}$.

\begin{tabular}{|c|c|c|c|c|c|c|}
\hline Country & $\bar{n}$ & Min & Max & Median & Mean & $\overline{\text { StDev }}$ \\
\hline Denmark & 12 & 1.67 & 58.9 & 3.98 & 11.98 & 18.8 \\
\hline England & 113 & 0.18 & 18.6 & 2.19 & 3.09 & 3.04 \\
\hline France & 3 & 1.28 & 3.16 & 1.32 & 1.92 & 1.07 \\
\hline Poland & 118 & 0.28 & 3.93 & 1.14 & 1.32 & 0.75 \\
\hline Mean & & 0.85 & 21.1 & 2.16 & 4.58 & 5.92 \\
\hline
\end{tabular}




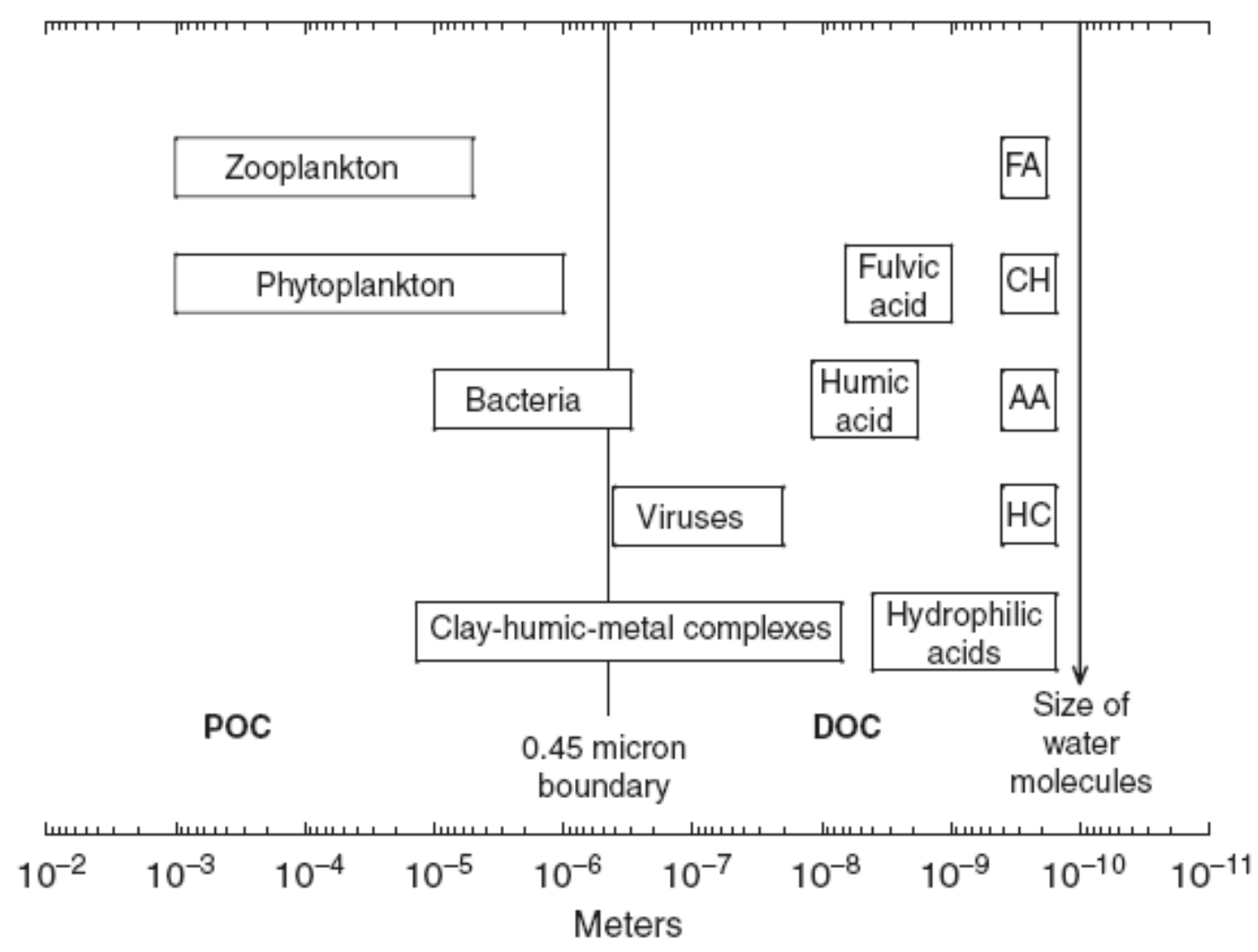

Figure 1. Continuum of particulate and dissolved organic carbon in natural waters.

FA-Fatty Acids; CH-Carbohydrates; AA-Amino Acids; HC-Hydrocarbons. TOC measurements include all the organic "compounds" shown above, DOC values include only the dissolved organic "compounds” which are to the right of the 0.45 micron boundary $(<0.45 \mu \mathrm{m})$. 


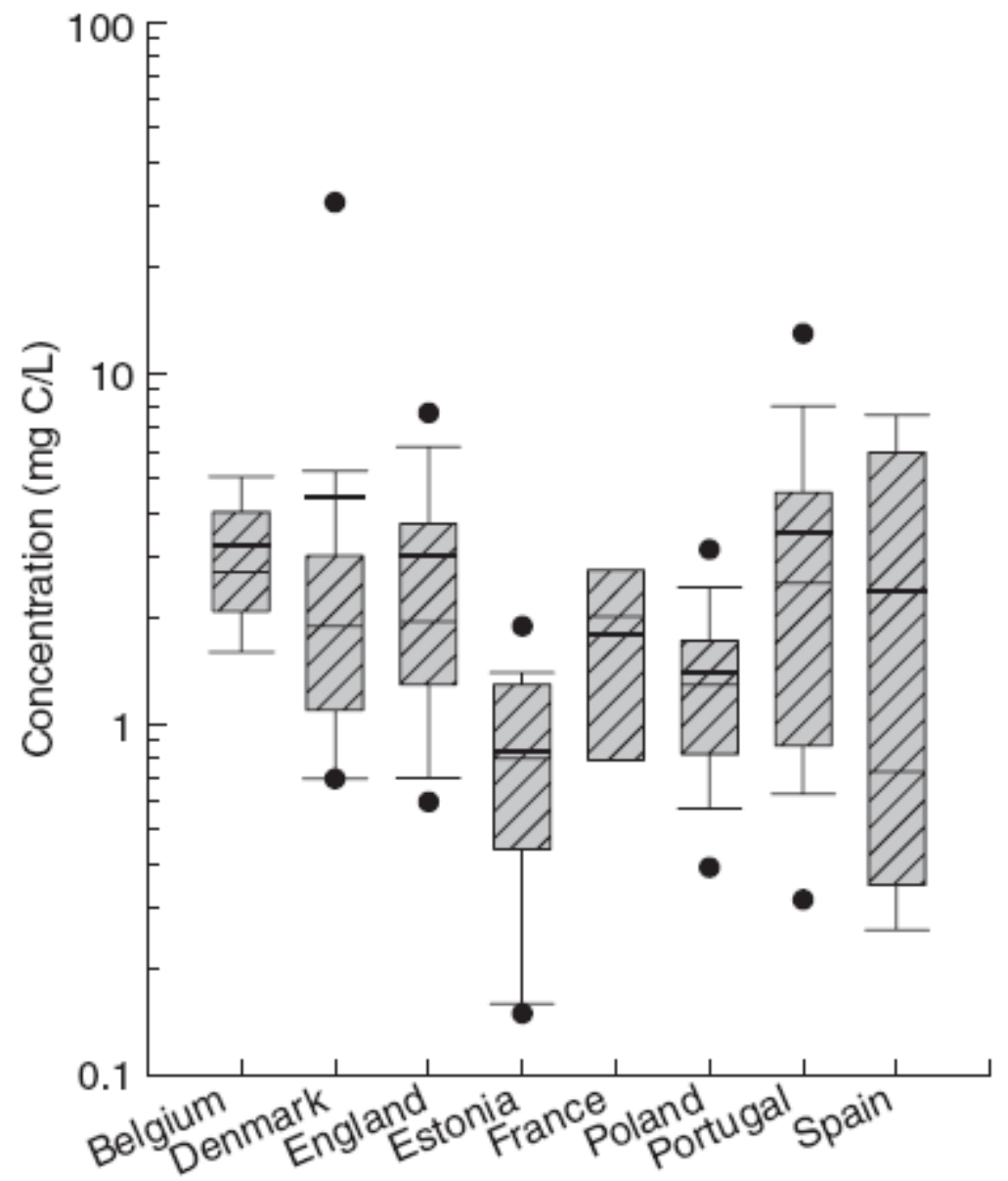

Figure 2. Box-Whisker plot of TOC concentrations in all European aquifers sampled. 


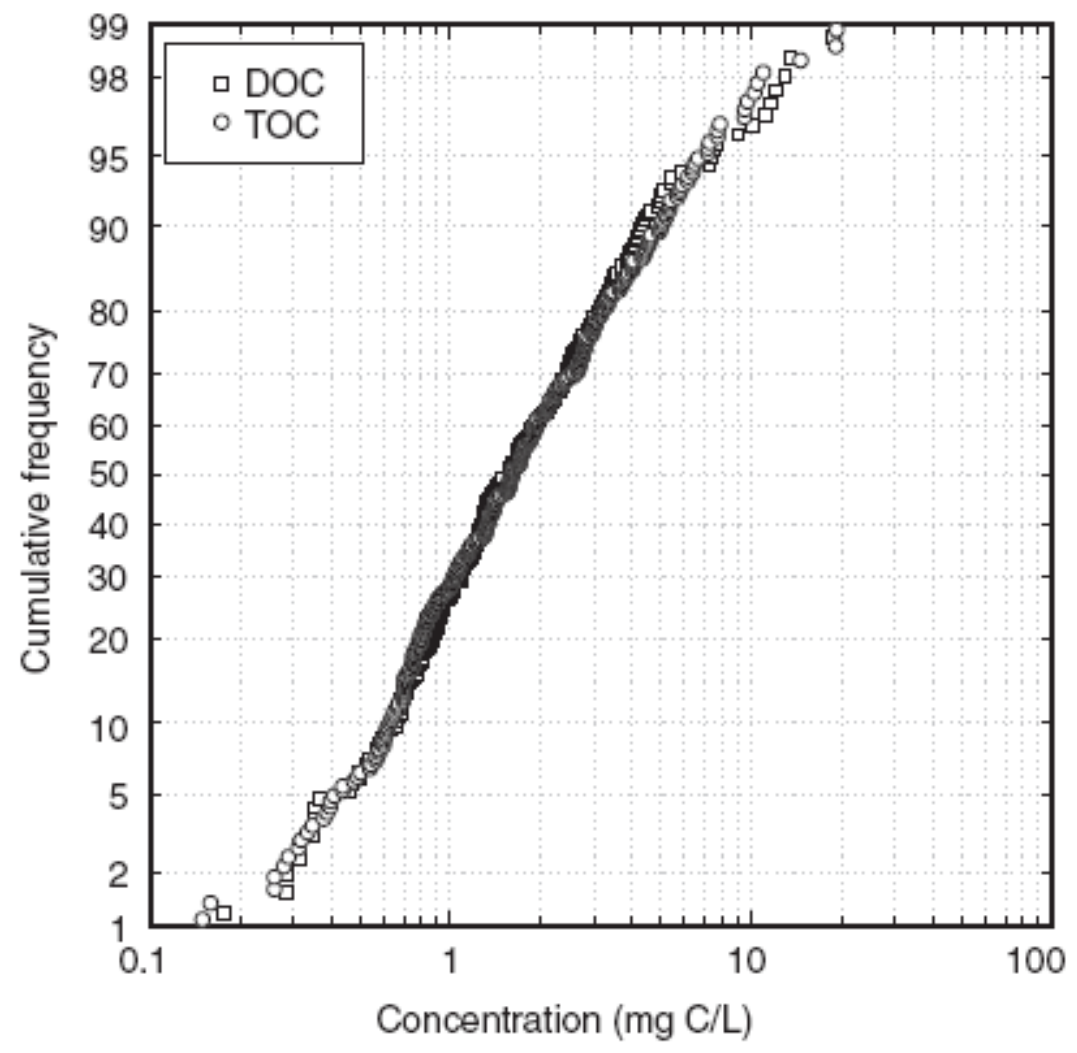

Figure 3. Cumulative frequency plot for both DOC and TOC from all European aquifers sampled. 


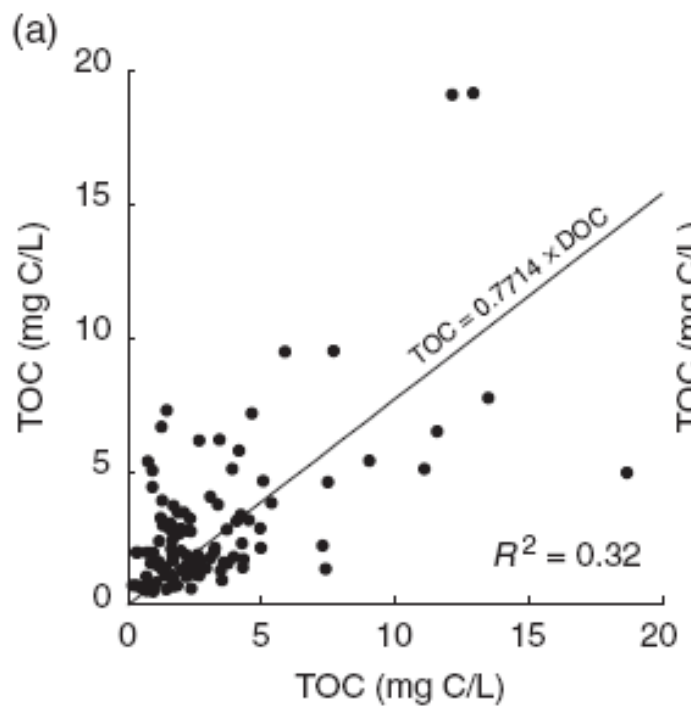

(b)

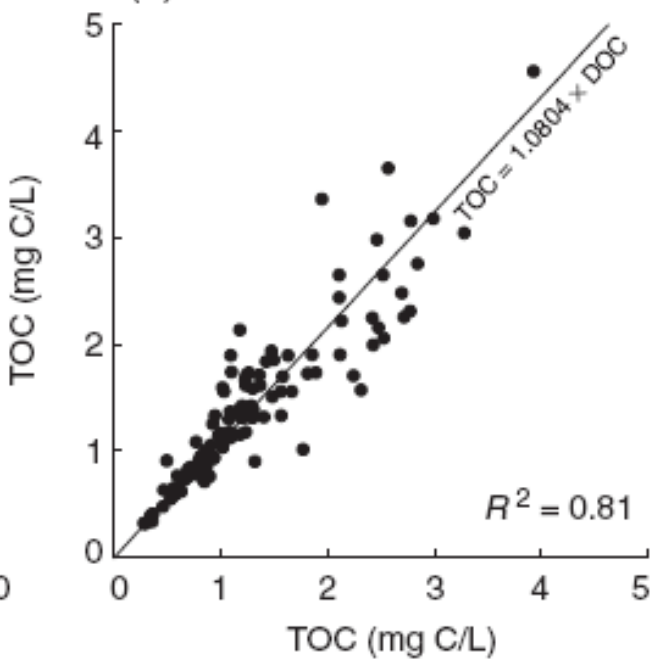

Figure 4. Cross plot of TOC and DOC from a) all UK aquifers sampled and b) all Polish aquifers sampled. 

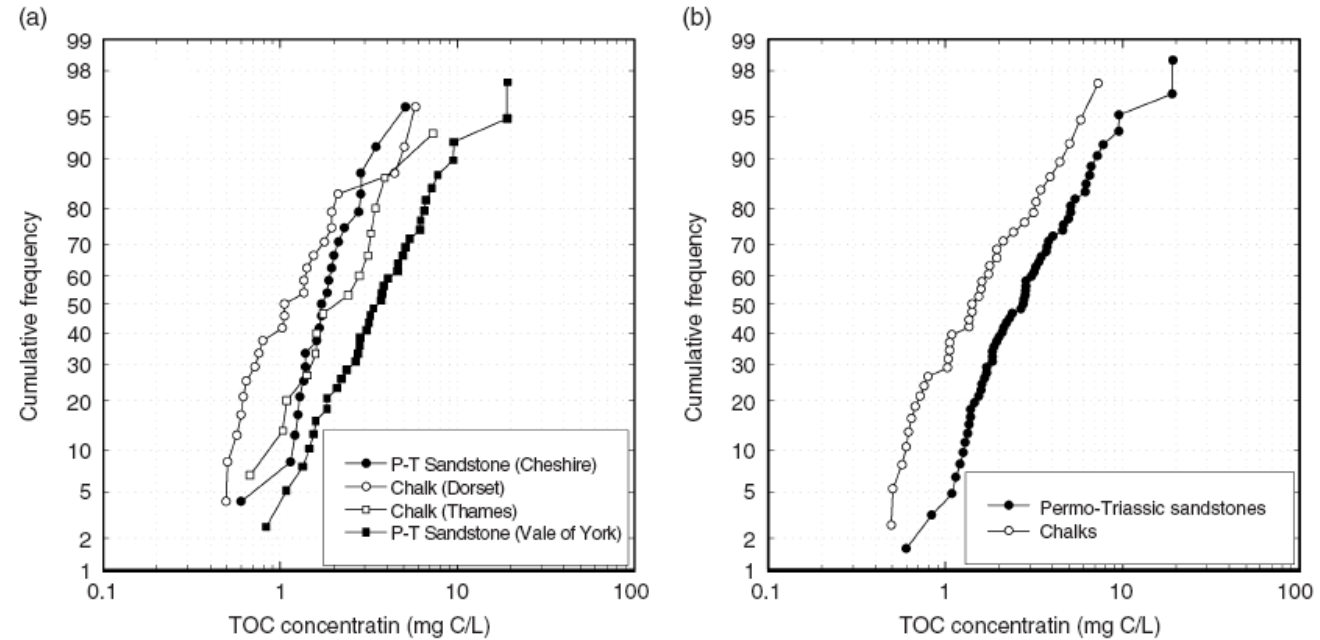

Figure 5. Cumulative frequency plot for a) TOC concentration in two Permo-Triassic sandstone and two Chalk aquifers from the UK and b) showing data as split by aquifer type and region 
(a)

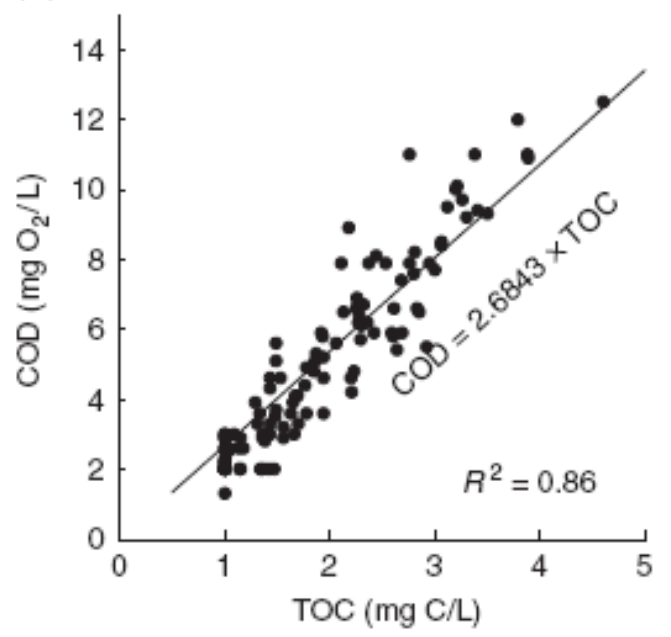

(b)

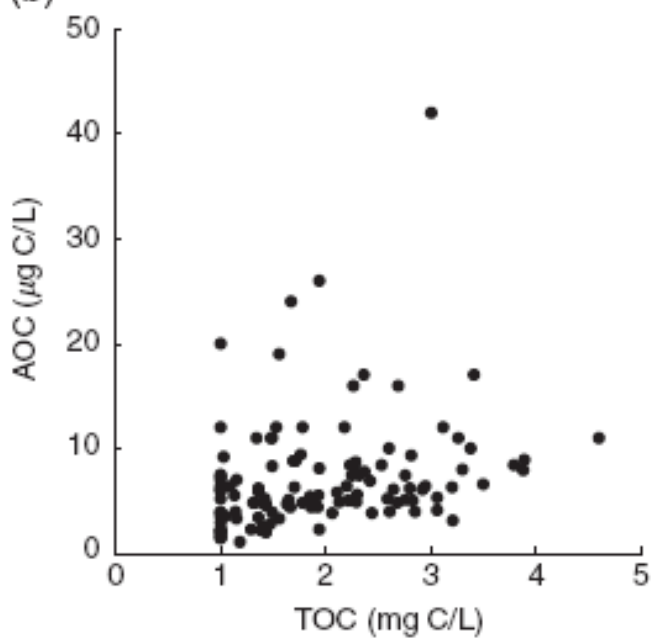

Figure 6. Samples taken from the Danish National Monitoring Programme showing a)

The relationship between chemical oxygen demand (COD) and TOC and b) the relationship between assimilable organic carbon (AOC) and TOC. 